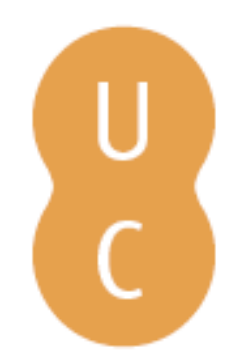

\title{
nombalina
}

\section{Comunidades educativas resilientes: perceção do risco e cultura de segurança}

Autor(es): $\quad$ Machado, André; Queirós, Margarida

Publicado por: Imprensa da Universidade de Coimbra

URL

persistente: URI:http://hdl.handle.net/10316.2/38286

DOI: $\quad$ DOI:http://dx.doi.org/10.14195/9789892610993_6

Accessed : $\quad$ 26-Apr-2023 14:57:46

A navegação consulta e descarregamento dos títulos inseridos nas Bibliotecas Digitais UC Digitalis, UC Pombalina e UC Impactum, pressupõem a aceitação plena e sem reservas dos Termos e Condições de Uso destas Bibliotecas Digitais, disponíveis em https://digitalis.uc.pt/pt-pt/termos.

Conforme exposto nos referidos Termos e Condições de Uso, o descarregamento de títulos de acesso restrito requer uma licença válida de autorização devendo o utilizador aceder ao(s) documento(s) a partir de um endereço de IP da instituição detentora da supramencionada licença.

Ao utilizador é apenas permitido o descarregamento para uso pessoal, pelo que o emprego do(s) título(s) descarregado(s) para outro fim, designadamente comercial, carece de autorização do respetivo autor ou editor da obra.

Na medida em que todas as obras da UC Digitalis se encontram protegidas pelo Código do Direito de Autor e Direitos Conexos e demais legislação aplicável, toda a cópia, parcial ou total, deste documento, nos casos em que é legalmente admitida, deverá conter ou fazer-se acompanhar por este aviso. 


\section{TERRAMOTO DE \\ LISBOA DE 1755}

\section{O QUE APRENDEMOS \\ 260 ANOS DEPOIS?}

LUCIANO LOURENÇO

ÂNGELA SANTOS

(COORDS.)

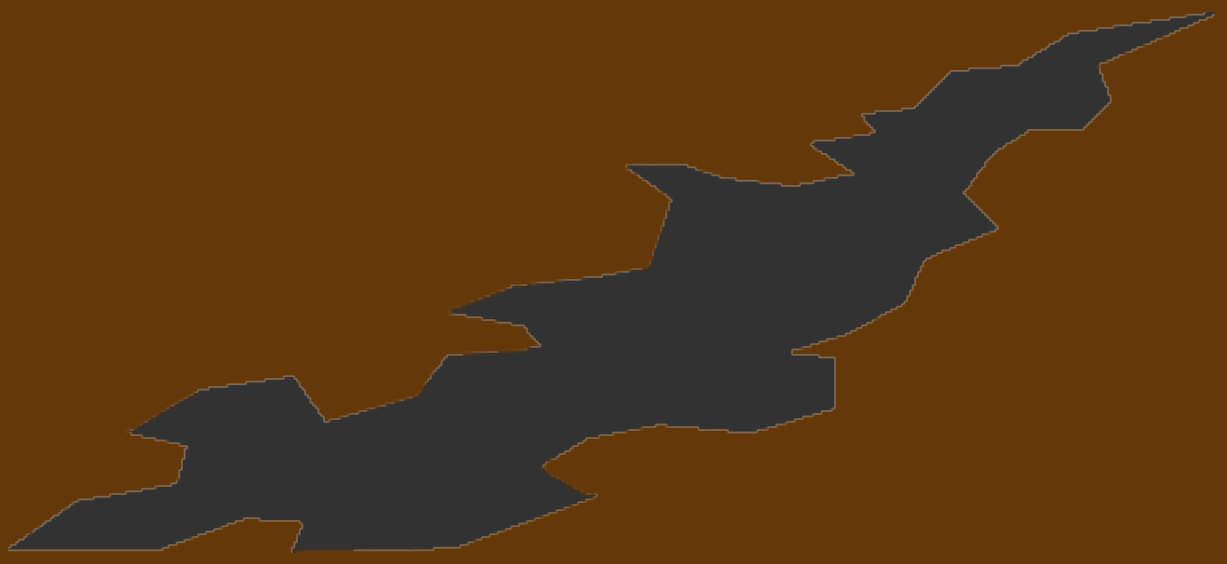

IMPRENSA DA UNIVERSIDADE

DE COIMBRA

COIMBRA

UNIVERSITY

PRESS 


\title{
COMUNIDADES EDUCATIVAS RESILIENTES: PERCEÇÁO DO RISCO E CULTURA DE SEGURANÇA ${ }^{1}$ \\ RESILIENT EDUCATIVE COMMUNITIES: RISK PERCEPTION AND SAFETY CULTURE
}

\author{
André Machado \\ Escola Secundária Eça de Queirós, Lisboa \\ andremachado45@yahoo.com \\ Margarida Queirós \\ Instituto de Geografia e Ordenamento do Território, \\ Centro de Estudos Geográficos, Universidade de Lisboa \\ margaridav@campus.ul.pt
}

Sumário: Conhecer a cultura de segurança numa comunidade educativa e avaliar como a perceção do risco é importante para a definição de medidas eficazes de sensibilização, gestão, mitigação e resiliência aos riscos foram os objetivos desta investigação. A realização de um inquérito permitiu conhecer as representações de professores, alunos e funcionários da Escola Secundária Eça de Queirós, em Lisboa, face a um conjunto diversificado de riscos (em particular, risco de incêndio e de sismo) no espaço escolar.

Palavras-chave: Comunidade Educativa : Perceção do Risco : Cultura de Segurança : Resiliência

\footnotetext{
${ }^{1}$ Este texto resulta de uma síntese e atualização de uma dissertação de Mestrado. Para aprofundamento do tema: Machado, A. (2012). Perceção do risco e implementação de uma cultura de segurança: construindo comunidades educativas resilientes. Dissertação de Mestrado em Populaçáo, Sociedade e Território. IGOT, Universidade de Lisboa, 114p. Disponível em: http://repositorio. ul.pt/handle/10451/9352.
} 


\begin{abstract}
This investigation aims to identify the safety culture in an educational community and to assess how the perception of risk is important for defining effective awareness measures, management, mitigation and resilience to risk. A survey was launched to recognise the representations of teachers, students and staff of the High School Eça de Queirós, in Lisbon, against a diverse set of risks (in particular, risk of fire and earthquake) at school.
\end{abstract}

Keywords: Educative community : risk perception : safety culture : resilience

\title{
Introduçáo
}

A sociedade contemporânea está a alargar o número e a complexidade das suas atividades que hoje se reconhece trazerem riscos de degradação do ambiente natural e da qualidade de vida. Se a tecnologia está em expansão, a organização social é mais complexa, interdependente, informada e reflexiva acerca dos riscos (U. Beck, 2006).

Até muito recentemente, os fenómenos naturais perigosos representavam a maior parte dos riscos para a sociedade, situação que se tem vindo a modificar pois o processo de rápida urbanização aliada ao progresso nos transportes e comunicaçóes a nível mundial, ao promover a concentração de população, infraestruturas e atividades económicas em espaços restritos, tornou as grandes aglomerações urbanas em espaços altamente vulneráveis não só aos riscos provocados por fenómenos naturais, como também aos de origem tecnológica e ambiental.

A tendência no incremento da frequência da ocorrência de fenómenos extremos e catástrofes, entendidas como acontecimentos excecionais aos quais apenas se podia responder com políticas reativas de ajuda de emergência, tem sido gradualmente substituída por uma outra perspetiva proativa, promovendo-se a redução dos riscos como solução sustentável para minimizar os impactos provocados pelas catástrofes na sociedade e na economia. Neste contexto, a defesa 
do direito e das aspiraçóes das populaçóes a uma maior segurança pressupóe a implementação de medidas efetivas de avaliação e mitigaçáo dos riscos, tanto por parte dos agentes com responsabilidades (por exemplo, as comunidades científicas e política), como pela sociedade civil, na ação individual/de grupo. Segundo M. Queirós (2000), as perceçôes individuais dos riscos, profundamente enraizadas no contexto social e individual, devem ser consideradas conjuntamente com os factos científicos na análise do risco. F. Bernardo (1997), E. Figueiredo et al. (2004) e M. Queirós et al. (2009) salientaram a importância da participação em processos de tomada de decisão sobre medidas de gestão e mitigação de riscos ambientais e tecnológicos; essa importância é devida ao contributo que a integraçáo das perceçôes das populaçóes locais, em conjunto com o conhecimento técnico e científico, pode dar para a legitimidade e eficácia daqueles processos (A. Delicado et al., 2007).

Estudos diversos reportam um claro crescimento das catástrofes ocorridas em Portugal, nomeadamente a partir de meados de década de 80 do século $\mathrm{XX}$, o que tem provocado um incremento do número total de perdas humanas e avultados danos económicos (J. Zêzere et tal., 2006, 2007a, 2007b; I. Quaresma, 2009). Todavia, a incorporação da perceção e valores na criação e implementação de medidas técnicas, associadas à mitigação e gestão dos riscos de origem tecnológica e ambiental, tem sido frequentemente negligenciada, reduzindo-se a participação pública a açôes de caráter pontual e, geralmente, com reduzido impacte nas decisóes técnicas e políticas (E. Figueiredo et al., 2004).

Tradicionalmente, a visão que as populaçóes tinham do risco era menosprezada por ser considerada irracional e subjetiva. Contudo, a investigação tem vindo a demonstrar que as pessoas são construtoras ativas de significado, interpretam o ambiente, resolvem ambiguidades e inferem relações causais (F. Bernardo, 1997). Assim, ao se pretender compreender como são selecionados os riscos que um indivíduo ou uma comunidade receia, deve procurar-se conhecer o modo como estes estruturam o seu pensamento sobre os riscos. Assim, a perceção do risco é produto do cruzamento da perigosidade estabelecida pelos riscos efetivos com as experiências vividas e varia de acordo com a condição económica, social e cultural do indivíduo (M. Queirós et al., 2006). 
Os indivíduos avaliam o risco de acordo com as suas perceções subjetivas e contextos de vida. Este processo mental de formação da perceção do risco é de extrema complexidade ao incluir as aprendizagens e experiências que o indivíduo adquiriu ao longo da sua vida e refletindo igualmente a sua esfera sociocultural e ideológica.

Estando o risco diretamente relacionado com as dinâmicas socioeconómicas específicas de cada contexto social e territorial, a dimensão e a intensidade do mesmo não só é percecionada diferentemente em contextos diversos, como o nível de aceitação, a adesão a medidas de mitigação e a capacidade de intervir na gestão são igualmente diversas. Pode-se por isso afirmar que, perante situaçóes de risco, cada contexto social desenvolve reaçóes e comportamentos próprios que se encontram dependentes das suas características socioculturais, económicas e territoriais (A. Machado, 2012).

Se o risco é socialmente construído, muitos dos julgamentos na sua base são influenciados por importantes fatores psicológicos, sociais, culturais e políticos (P. Slovic, 2000, 2010). Assim, a integração da perceção do risco na análise, avaliação e comunicação do risco, tem-se revelado importante na eficácia dos processos de decisão, ao legitimar as medidas de gestão e mitigação adotadas e permitindo uma maior e eficaz adesão das mesmas junto da população-alvo, neste caso concreto, as pessoas que constituem a Comunidade Escolar $^{2}$ (CE) da Escola Secundária Eça de Queirós (ESEQ), em Lisboa.

Esta investigação demonstra que a perceção que os indivíduos que constituem a CE da ESEQ têm do risco, varia de acordo com as características do mesmo e a informação adquirida; revela ainda que os comportamentos (práticas) manifestados pela referida comunidade face ao risco variam consoante as representaçóes do risco, as suas características sociodemográficas e o grau de confiança nas instituiçóes. Conclui-se por isso que a forma como os elementos da CE percecionam o risco condiciona a definição de estratégias eficazes de

\footnotetext{
${ }^{2} \mathrm{Na}$ Comunidade Escolar (CE) consideram-se todos os alunos, docentes, assistentes operacionais e assistentes técnicos frequentadores habituais do espaço escolar nos Olivais-Sul, Lisboa, e durante um determinado período temporal (neste caso, o ano lectivo de 2010/2011).
} 
sensibilização, gestão e mitigação dos riscos conducentes à implementação de uma cultura de segurança e à constituição de uma comunidade resiliente face às emergências (A. Machado, 2012).

\section{O risco em estabelecimentos escolares: a função essencial da educaçáo e formação na sensibilizaçáo para os riscos}

De acordo com M. Kano et al., 2007, apesar da abundante e diversificada literatura científica sobre a perceçáo e o comportamento em relação ao risco e em resposta às catástrofes naturais e aos acidentes de grande magnitude e impacto, deveria existir mais pesquisa e estudos sobre os temas da perceção e prevenção do risco nas organizaçóes e instituiçóes públicas, com particular relevância para os estabelecimentos de ensino básico e secundário. Todavia, em Portugal, alguns estudos foram já realizados sobre esta temática (ver M. Inácio, 2010, A. Machado, 2012)

Segundo M. Kano et al., 2007, uma elevada percentagem de escolas básicas e secundárias cumprem o normativo legal, isto é, possuem extintores, realizam inspeções de segurança às instalaçóes e aos equipamentos de primeiro socorro e possuem planos de prevençáo e emergência, mas raramente reportam qualquer informaçáo sobre medidas e atividades de preparação da sua populaçáo, especialmente para situaçôes de emergência de grande escala, nomeadamente em situaçôes de incêndio e de sismo (M. Kano et al., 2007). Alguns estudos dedicados à avaliação da preparação das escolas para lidar com situaçóes imprevistas provocadas por fenómenos perigosos, chegam a conclusôes pouco animadoras. Um dos estudos conclui que a maioria das escolas não realizava exercícios de emergência com regularidade e registavam uma insuficiente comunicação com os pais e encarregados de educaçáo sobre os procedimentos a tomar em situaçôes de crise. Outro (M. Kano et al., 2007), refere que a maioria das escolas náo previa medidas de segurança para as crianças com necessidades especiais e náo se coordenavam com as forças locais de proteção civil. 
A literatura relativa à prevenção para a emergência refere que é frequente as instituiçôes públicas assumirem que estão preparadas e seguras a partir do momento em que disponham de um plano de emergência. Contudo, os planos de prevenção e emergência só são eficazes com a disponibilidade de meios de primeiro socorro e a realizaçáo regular de exercícios de evacuaçáo (M. Kano et al., 2007, M. Inácio, 2010). Porém, a prevenção para a emergência implica uma reflexáo sobre o risco e a perceção que dele se tem, compreende náo apenas investimentos em tecnologias de segurança passivas e despesas em manutenção ou fiscalização dos edifícios, mas também, ações de informação e participação ativa nos processos de educação para a prevenção, para os quais é pertinente conhecer como as pessoas percecionam o risco.

Em contexto escolar, o factor decisivo para uma resposta adequada à emergência encontra-se na preparação antecipada. Contudo, só será eficaz se existir uma cultura de segurança na CE para que os envolvidos sintam uma efetiva preocupação com a sua própria segurança, promovendo de forma ativa e consciente as medidas de autoproteção, convertendo-se assim nos primeiros agentes de proteção civil, não só na escola, como também nos demais cenários e contextos do quotidiano (A. Machado, 2012).

Uma resposta adequada à emergência não será sólida se os fatores que intervêm e condicionam a perceção e o comportamento face aos riscos por parte dos diferentes elementos que constituem a CE forem desconhecidos. A experiência demonstrou os efeitos positivos da educação na reduçáo do risco; as sociedades familiarizadas e preparadas para os acidentes demonstram que a educação pode contribuir de forma decisiva para a sua proteção nos momentos de gestão das crises (ISDR, 2005). Os programas curriculares do ensino básico e secundário assumem uma particular importância numa estratégia de implementação e desenvolvimento de uma cultura de prevenção, pois permitem lecionar-se temas relacionados com os perigos, os riscos e as vulnerabilidades a que estão expostas as comunidades (M. Inácio, 2010), possibilitando não só um melhor conhecimento e perceção das características do meio local em que os jovens vivem, como também um estímulo para a transmissão aos familiares e amigos dos conhecimentos relacionadas com as medidas e os comportamentos 
adequados face às emergências (ISDR, 2005; M. Queirós e A. Santos, 2013; A. Santos e M. Queirós, 2015).

As escolas ocupam uma posição central em qualquer comunidade, pois constituem um elo de ligação entre os elementos das diferentes geraçóes, conferindo-lhes assim um papel privilegiado na sensibilização e consciencialização da sociedade para os riscos e perigos. Contudo, até recentemente, muito pouco se tem realizado de forma sistemática neste sentido, desperdiçando-se assim um valioso recurso, tendo ainda em consideração o facto de os jovens e as famílias constituírem dois grupos com maior vulnerabilidade aos efeitos de um desastre.

Atualmente, os modelos de prevenção e de resposta aos desastres incorporam a resiliência, conceito que traduz o objetivo da adequada preparaçáo das comunidades para absorver distúrbios e recuperar de um evento danoso no mais curto espaço de tempo possível sem perder a sua identidade. O conceito de resiliência foi pela primeira vez aplicado aos sistemas ecológicos (ecossistemas) por Holling (1973), para descrever a propriedade de manutenção dos sistemas naturais face a mudanças nos ecossistemas provocadas tanto por causas naturais como humanas. Assim, o conceito de resiliência foi inicialmente definido como a quantidade de perturbação que um sistema pode absorver sem mudar de estado. Este conceito de resiliência foi adotado pela física e pela engenharia, sendo por isso sido designado por Holling como engineering resilience (Holling, 1973).

Segundo Walker et al., (2002) citado em Santos e Partidário, (2011), o principal objetivo na gestão da resiliência de um sistema é impedir que evolua para situação indesejáveis quando sujeito a perturbaçóes externas. Mais tarde, Holling e Walker et al. (2004), propuseram um conceito de resiliência aplicado aos sistemas socioecológicos, referindo-se à capacidade de um sistema absorver perturbaçóes e reorganizar-se, quando sujeito a forças de mudança, sendo capaz de manter as suas funçóes, estrutura, identidade e mecanismos de funcionamento.

Ao ser transposto para um sistema social, como é uma comunidade escolar, o conceito de resiliência não é sinónimo de invulnerabilidade. Exprime ter "consciência" das próprias vulnerabilidades para conseguir adaptar-se às circunstâncias imprevistas, conseguindo retirar experiência delas em seu proveito (absorvê-las) e utilizá-las para reorganizar a situaçáo. Uma comunidade 
escolar resiliente apresenta um baixo risco de alteração. Quando ocorre uma perturbação, o sistema CE tem a capacidade de se reorganizar, permitindo manter no essencial as suas funçóes, estrutura e identidade. Uma escola que: i) durante e após um "choque" garanta um número mínimo de componentes funcionais (operacionais) em funcionamento, ii) que esses elementos possam ser suficientemente diversificados para garantir a proteção da escola contra os danos provocados, iii) de forma rápida e eficiente e iv) sendo capaz de tudo isto autonomamente, entáo a CE apresenta as caraterísticas de um sistema resiliente. Estas componentes da CE funcionam de forma colaborativa, em rede, estão interligadas e são capazes de aprender com a experiência para acomodar a mudança (auto-organizadas). No presente caso, o objetivo da pesquisa foi o de ajudar a comunidade escolar a preparar-se para um acontecimento perigoso, minimizar os danos e recuperar tanto física como psicologicamente. Para tal foi preciso começar por perceber como a CE equaciona o risco.

\section{O caso de estudo: enquadramento territorial e social}

A Escola Secundária Eça de Queirós (ESEQ) é uma instituição pública, e situa-se na rua Cidade de Benguela no bairro dos Olivais-Sul, em Lisboa (fig. 1). A sua localização coloca-a numa situação de vulnerabilidade sísmica considerável, mas livre do risco de tsunami pela altitude relativamente elevada em relação ao rio Tejo e com diminuto risco de inundação por se edificar numa pequena encosta com um declive acentuado.

De acordo com a carta da vulnerabilidade sísmica dos solos (segundo o Relatório da Proposta Preliminar de Revisão do PDM de Lisboa, julho de 2009), a ESEQ encontra-se edificada numa área onde a natureza dos solos lhes confere uma vulnerabilidade média aos sismos (formaçóes argilosas consolidadas, rochas de baixa resistência/solos coerentes rijos, rochas brandas). Está situada numa vertente, a cerca de 1400 metros de distância da margem ribeirinha do rio Tejo, a uma altitude média aproximada de $55 \mathrm{~m}$. 


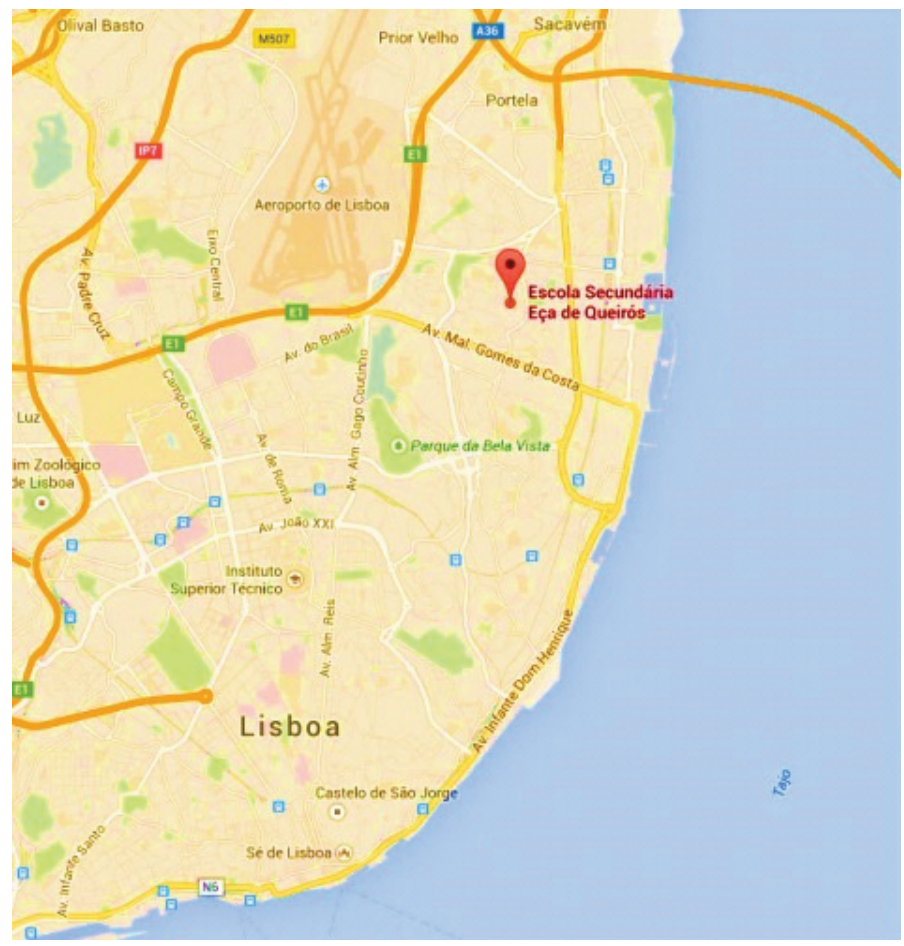

Fig. 1 - Localização da Escola Secundária Eça de Queirós no bairro dos Olivais-Sul, Lisboa (Fonte: Google Maps). Coordenadas Geográficas do Edifício Central: Latitude: $38^{\circ} 45^{\prime} \mathrm{N}$; Longitude: 09 06’ O; Altitude média: $55 \mathrm{~m}$.

Fig. 1 - Location High School Eca de Queirós in the neighborhood of Olivais Sul, Lisbon (Source: Google Maps) Geographic coordinates of the Central Building: Latitude: $38^{\circ}$ $45^{~ ' N}$; Longitude: $09^{\circ} 06^{\prime} \mathrm{O}$; average Altitude: $55 \mathrm{~m}$.

Nesta escola eram lecionados em 2010/2011 os cursos dos ensinos básico, secundário, ensino secundário recorrente noturno por módulos capitalizáveis e os cursos de educação e formaçáo de adultos, num total de 1070 estudantes do regime diurno (704) e noturno (366). Em ambos os turnos, frequentava esta escola uma população discente heterogénea, tanto em termos étnicos e culturais como sob o ponto de vista etário e social, o que constitui um interessante e adequado universo para o tema em estudo. Fazem ainda parte do universo em estudo, o pessoal docente (153) e assistentes, operacionais e técnicos (33) (A. Machado, 2012). 


\section{Metodologia}

A ausência de informação oficial sobre o tema e a heterogeneidade da CE em estudo torna-a difícil de avaliar. Como se pretendeu compreender e interpretar como os sujeitos que a compóem experienciam, pensam e agem (que valores, representaçôes, crenças, opinióes e atitudes), relativamente a situaçóes de risco nos espaços considerados e, dada a inexistência de outra fonte de informaçáo disponível, a metodologia utilizada para a realizaçáo do referido estudo de perceção de risco contou com o desenho e lançamento de um questionário à CE da ESEQ autorizado pela Direção. Os inquiridos responderam de forma voluntária, após a realização de três sessōes de esclarecimento sobre as questôes e os objetivos a atingir, tendo o primeiro autor estado sempre presente em todas as sessôes de resposta para o esclarecimento de qualquer dúvida.

Os alunos e os assistentes técnicos e operacionais acederam e responderam ao inquérito através do servidor da escola, em salas de aula TIC; os docentes tiveram acesso ao site através do envio autorizado do respectivo link de acesso para os e-mails de 56 professores, dos quais 36 responderam em tempo útil ${ }^{3}$.

Para a conceção dos questionários foi consultada bibliografia relativa à sociologia do risco e estudos de perceção do risco, a partir da qual foram definidos os temas considerados relevantes para a análise das representaçốes e práticas da $\mathrm{CE}$ face a um conjunto diversificado de riscos. Os questionários foram estruturados de acordo com sete tópicos (TABELA I), a partir dos quais foi desenhado o "questionário de perceção de riscos na CE" que foi aplicado à CE da ESEQ no ano letivo de 2010/11.

À exceção dos assistentes técnicos, o número de questionários realizados foi superior ao necessário, o que se justificou pelo facto de os mesmos terem sido executados em grupo/turma ou, no caso dos docentes, dentro do prazo

\footnotetext{
${ }^{3}$ Foram ainda realizadas entrevistas a atores-chave da comunidade escolar (professores delegados e coordenadores), a responsáveis de instituiçôes de segurança e proteçấo civil (bombeiros, serviços municipalizados de proteção civil), e professores delegados de segurança de escolas públicas em Lisboa. Essa informaçáo năo foi utilizada neste texto; todavia para aprofundamento cf. A. Machado (2012).
} 
TABELA I - Tópicos e objetivos no desenho dos questionários. TABLE I - Topics and objectives in the design of the questionnaires.

\begin{tabular}{|c|c|}
\hline Tópicos & Objetivos \\
\hline $\begin{array}{l}\text { 1. Perfil sociodemográfico } \\
\text { dos inquiridos }\end{array}$ & $\begin{array}{l}\text { Conhecer o perfil sociodemográfico da populaçáo inquirida (idade, sexo, } \\
\text { nacionalidade, habilitaçôes literárias/escolaridade, local de residência e } \\
\text { profissấo e escolaridade dos pais/encarregados de educaçáo dos alunos. }\end{array}$ \\
\hline $\begin{array}{l}\text { 2. Sentimento geral de se- } \\
\text { gurança }\end{array}$ & $\begin{array}{l}\text { Avaliar o sentimento de segurança experienciado pela CE no seu quotidiano } \\
\text { e nos espaços considerados; } \\
\text { Avaliar diferenças significativas nas representaçóes mentais face aos riscos } \\
\text { por parte dos diferentes elementos da comunidade escolar. }\end{array}$ \\
\hline $\begin{array}{l}\text { 3. Perceção aos riscos } \\
\text { naturais, ambientais, tec- } \\
\text { nológicos e humanos nos } \\
\text { espaços considerados }\end{array}$ & $\begin{array}{l}\text { Analisar como a CE perceciona os perigos nos diferentes espaços (em casa, } \\
\text { na escola, no bairro dos Olivais e na cidade de Lisboa), através do grau de } \\
\text { preocupaçáo suscitado e da sua probabilidade de ocorrência; } \\
\text { Avaliar diferenças significativas nas perceçôes face aos riscos. }\end{array}$ \\
\hline $\begin{array}{l}\text { 4. Caracterizaçấo dos peri- } \\
\text { gos mais preocupantes em } \\
\text { casa e na escola }\end{array}$ & $\begin{array}{l}\text { Analisar como a CE perceciona os perigos nos espaços considerados; } \\
\text { Avaliar diferenças significativas nas perceçóes, representaçóes mentais e } \\
\text { comportamentos face aos riscos por parte dos diferentes elementos da CE. }\end{array}$ \\
\hline $\begin{array}{l}\text { 5. Perceçáo da frequência } \\
\text { dos riscos no espaço escolar }\end{array}$ & $\begin{array}{l}\text { Analisar como a CE perceciona a frequência dos riscos no espaço consi- } \\
\text { derado; } \\
\text { Avaliar eventuais diferenças significativas nas perceçóes e representaçóes } \\
\text { mentais face aos riscos por parte dos diferentes elementos da CE. }\end{array}$ \\
\hline $\begin{array}{l}\text { 6. Confiança nos agentes e } \\
\text { instituiçōes fonte de infor- } \\
\text { maçáo sobre riscos }\end{array}$ & $\begin{array}{l}\text { Avaliar a confiança depositada na informação transmitida pelas diferentes } \\
\text { instituiçóes e entidades com responsabilidades na comunicaçáo, na segu- } \\
\text { rança e na proteçấo civil; } \\
\text { Avaliar eventuais diferenças significativas nas perceçóes e representaçóes } \\
\text { mentais face aos riscos por parte dos diferentes elementos da CE. }\end{array}$ \\
\hline $\begin{array}{l}\text { 7. Participaçáo pessoal, } \\
\text { conhecimento, prevenção } \\
\text { e experiência pessoal dos } \\
\text { riscos }\end{array}$ & $\begin{array}{l}\text { Avaliar o grau de participação dos elementos da CE em relação aos riscos, } \\
\text { nomeadamente como se informam e que conhecimentos e medidas de } \\
\text { prevenção costumam tomar; } \\
\text { Avaliar o conhecimento de comportamentos adequados em caso de emer- } \\
\text { gência e a experiência pessoal com situaçôes de incêndio e sismo; } \\
\text { Avaliar eventuais diferenças significativas nas perceçóes, representaçóes } \\
\text { mentais e comportamentos face aos riscos por parte dos diferentes elementos } \\
\text { da CE. } \\
\text { Analisar como a perceção dos riscos determina a definição de estratégias } \\
\text { eficazes de sensibilizaçâo, gestáo, mitigação e resiliência aos riscos. }\end{array}$ \\
\hline
\end{tabular}

útil de resposta. Assim, de um total calculado em 202, foram considerados válidos um total de 210 questionários, repartidos pelas diferentes categorias de elementos da CE.

Os questionários foram constituídos com questóes de resposta fechada para um tratamento estatístico objetivo, segundo uma amostragem estratificada representativa. A dimensão da amostra foi calculada de acordo com uma tabela a 99,9\%, para uma margem de erro inferior a 0.5\% (D. Abreu, 2006: A-105), a partir da qual foi apurado o número de questionários a realizar em cada categoria da população (TABELA II). 
TABELA II - Docentes, Alunos, Assistentes Operacionais e Técnicos, ESEQ (ano letivo 2010/2011)

TABLE II - Teachers, Students, Operational and Technical Assistants, ESEQ (academic year 2010/2011)

\begin{tabular}{|l|c|c|c|c|c|}
\hline Comunidade Escolar & $\mathbf{H}$ & $\mathbf{M}$ & Total & $\begin{array}{c}\text { Questionários a realizar } \\
\text { (margem de erro: 0,1\%) }\end{array}$ & $\begin{array}{c}\text { Questionários } \\
\text { realizados }\end{array}$ \\
\hline Docentes & 58 & 95 & 153 & 35 & 36 \\
\hline Alunos & 388 & 682 & 1070 & 142 & 144 \\
\hline Assistentes Operacionais & 5 & 16 & 21 & 15 & 20 \\
\hline Assistentes Técnicos & -- & 12 & 12 & 10 & 10 \\
\hline TOTAL & 451 & 805 & 1256 & 202 & 210 \\
\hline
\end{tabular}

Fonte/Source: A. Machado (2012)

O questionário foi construído com recurso ao software disponibilizado pela Google.com, e acedido através do servidor da escola; foi alojado num sítio internet criado para o efeito, tendo ficado disponível no endereço electrónico: https://sites. google.com/alqueiroz.pt/percepcao-de-riscos-eca-de-queiros/home onde constou ainda uma página com informaçáo de contextualizaçáo, a estrutura e os objetivos a alcançar com a sua realizaçáo, tendo o prazo útil de acesso e resposta decorrido entre os dias 16 de fevereiro e 11 de março de 2011 (A. Machado, 2012).

A informação relativa às respostas dadas ia sendo contabilizada numa spreadsheet anexa ao questionário, de onde foi posteriormente exportada para uma folha de Excel, a partir da qual se constituiu uma base de dados para o tratamento estatístico e gráfico da informação.

Segurança e perceçáo do risco: análise do questionário à Comunidade Escolar da ESEQ

Perfil dos inquiridos: breve síntese

A análise do perfil sociodemográfico dos inquiridos da $\mathrm{CE}$, permite náo só o conhecimento da sua estrutura, de acordo com as variáveis consideradas 
mais significativas neste estudo, como também averiguar que relaçôes se estabelecem entre as características sociodemográficas dos inquiridos e o modo como se relacionam com o risco, ou seja, se variáveis como o sexo, a idade e a escolaridade, interferem nas perceçôes, atitudes e comportamentos relacionados com os riscos. Sempre que a análise da informação sugeriu a pertinência de alguma destas variáveis na explicação dos dados obtidos, procedeu-se à sua interpretação de forma mais específica e contextualizada.

A fig. 2 representa a composição etária percentual dos inquiridos. O elevado valor de pessoas pertencentes ao escalão etário superior, fica a dever-se ao facto de a maioria dos docentes, dos alunos dos cursos noturnos e dos assistentes operacionais terem idades superiores aos 40 anos. Foi registada uma predominância de indivíduos do sexo feminino na $\mathrm{CE}$ devido ao maior número de alunos, de docentes, de assistentes operacionais e técnicos daquele sexo.

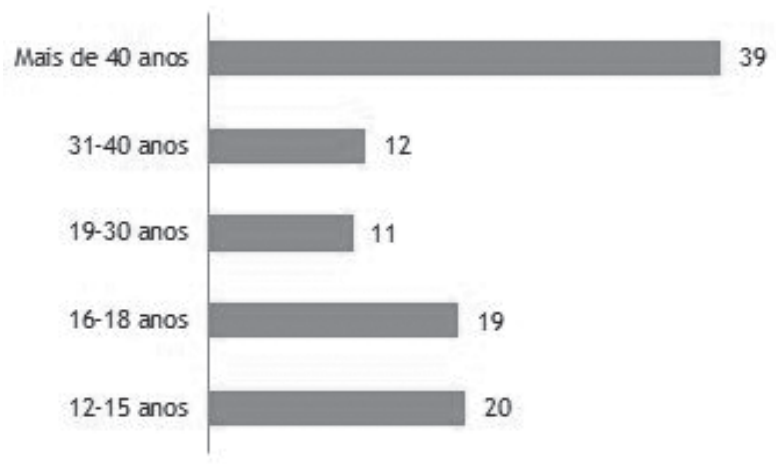

Fig. 2 - Composição etária da população inquirida (\%) (Fonte: A. Machado, 2012). Fig. 2 - Age composition of the population surveyed (\%) (Source: A. Machado, 2012).

O gráfico da fig. 3 representa a dimensão percentual de cada uma das categorias de elementos da CE na amostra em estudo, verificando-se uma óbvia e esperada preponderância dos estudantes.

$\mathrm{Na}$ composição da amostra dos estudantes, constatou-se que a maioria frequentava o ciclo de estudos do ensino secundário (54\%), não tendo sido possível questionar os alunos inscritos nos cursos secundários por módulos capitalizáveis por indisponibilidade no acesso às salas TIC. 


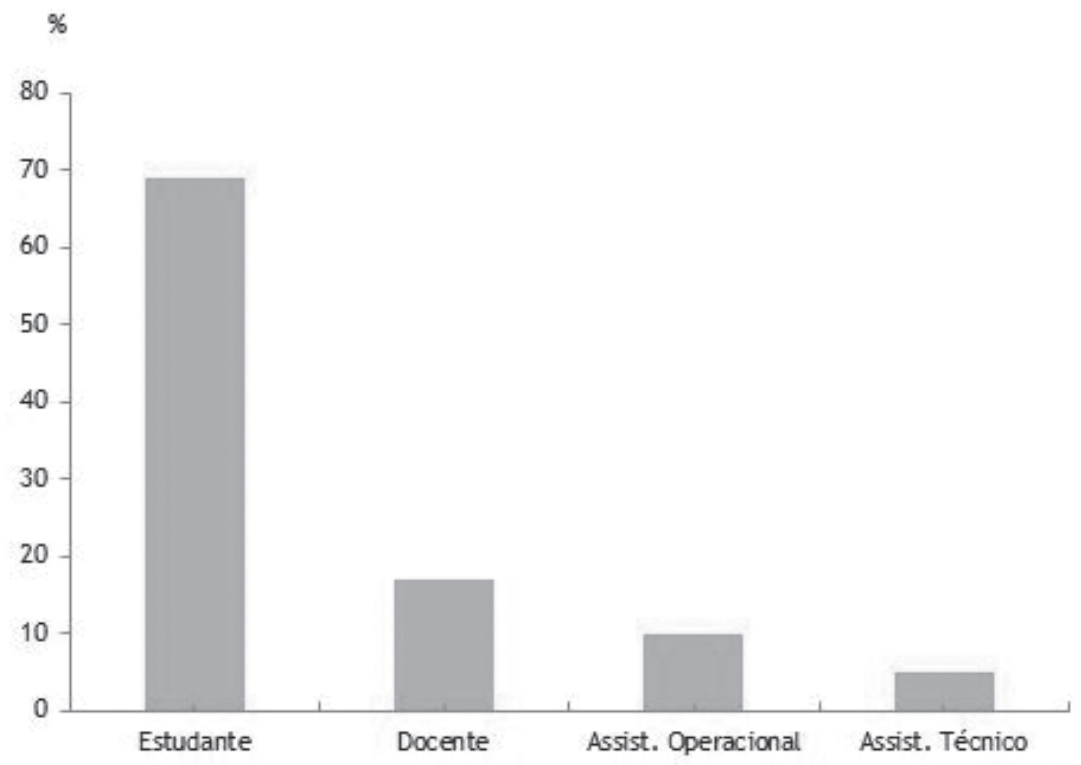

Fig. 3 - Estatuto dos inquiridos (\%) (Fonte: A. Machado, 2012).

Fig. 3 - Status of the respondents (\%) (Source: A. Machado, 2012).

Sentimento geral de (in)segurança percebido pelos elementos da Comunidade Escolar

No sentido de avaliar o sentimento geral de segurança dos elementos da CE (tópico 2 da TABELA I), foi pedido aos inquiridos que qualificassem como se sentiam no dia a dia tendo em conta os riscos que correm, de acordo com uma escala ordinal de 5 níveis (de 1 - bastante seguro, a 5 - bastante inseguro). Os resultados obtidos revelaram que a imensa maioria (92\%) se sentia entre relativamente seguro e bastante seguro no seu quotidiano, contrastando com uma minoria que relatou um sentimento de insegurança (8\%), correspondente às opçôes de relativamente inseguro e bastante inseguro. Estes dados parecem sugerir, tal como foi constatado noutros estudos (M. Queirós et al., 2009), que não existe uma perceção alargada de perigo entre a população inquirida, existindo um sentimento de segurança generalizado, apenas não partilhado por um pequeno grupo que não chega aos $10 \%$ dos inquiridos. 
Alguma literatura académica tem salientado a heterogeneidade das preocupaçôes das pessoas acerca dos riscos que correm (G. Frias, 2004; M.L. Lima, 2004 e 2005; M. Queirós et al., 2009). Assim, foi detetado existir uma relação entre o sexo e sentimentos de insegurança, com as mulheres a registarem níveis mais elevados de preocupação e de ameaça, assim como por parte dos grupos socialmente menos favorecidos, isto é, nos menos escolarizados e com menores rendimentos e nos mais idosos. Esta evidência poderia ser explicada pelo menor acesso à informaçáo, maior dificuldade em a descodificar, escolhas mais limitadas e menor capacidade de agir de forma a evitar um risco (M.L. Lima, 2005; A. Delicado et al., 2007).

Pretendeu-se ainda avaliar o grau de segurança percebido em cada um dos quatro espaços considerados no questionário, a saber: casa, escola, bairro dos Olivais e cidade de Lisboa. A sua análise permite afirmar que, tal como já foi constatado relativamente ao sentimento geral de segurança, os indivíduos sentiam-se maioritariamente seguros (desde relativamente seguros a bastante seguros) em todos os espaços, registando o espaço da escola um valor de respostas ligeiramente superior (206) ao do registado para casa (200).

$\mathrm{O}$ maior sentimento de insegurança evidenciado em relaçấo ao bairro dos Olivais e à cidade de Lisboa (27 e 38 respostas, respetivamente), apresenta contudo valores significativamente reduzidos, tal como no que diz respeito à percentagem de respostas relativas à tendência da evoluçáo futura da diminuiçáo da segurança, repetidamente mais evidentes para o bairro dos Olivais (15\%) e para a cidade de Lisboa (20\%). Apesar de pouco significativa, esta perceçáo de insegurança, novamente maioritária nos indivíduos do sexo feminino com idade mais avançada, poderá explicar-se também pela sua maior vulnerabilidade física, o seu papel na proteção e prestação de cuidados à família e a capacidade em assumir com mais naturalidade os seus medos, colocando-os numa situação de maior ansiedade relativamente à insegurança percebida.

Ainda relativamente à tendência da evolução futura da segurança em cada um dos espaços considerados (fig. 4), constatou-se que a maioria dos respondentes entendia que a segurança se iria manter (em casa e na escola) e aumentar (no bairro dos Olivais e na cidade de Lisboa), contrariando as 
opiniốes pessimistas obtidas tanto noutros inquéritos nacionais como em estudos internacionais. O estudo das estratégias mentais ou heurísticas que as populaçóes usam para dar sentido a um mundo incerto (F. Bernardo, 1997), e que leva a enviesamentos relacionados com a presença de situaçóes de incerteza e insegurança, pode trazer alteraçóes da perceção em termos de estimativa de risco e do seu impacto.

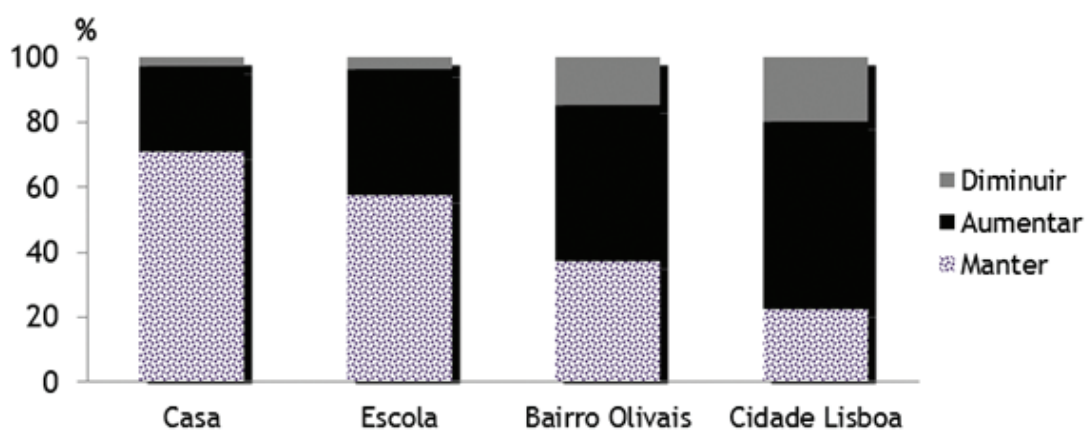

Fig. 4 - Evolução futura da segurança (Fonte: A. Machado, 2012).

Fig. 4 - Evolution of future safety (Source: A. Machado, 2012).

Estudos de psicologia cognitiva (M.L. Lima, 2004) mostram que tendemos a evitar a incerteza, o que necessariamente enviesa a avaliaçáo dos riscos. Esta estratégia mental ou heurística da evitação da incerteza pode levar a uma tendência de negação do risco a que as pessoas estão sujeitas (M. Lima, 2005). Ficam patentes os elevados valores do sentimento geral de segurança no dia a dia, nos diferentes espaços (nomeadamente em casa e na escola), e na manutenção/aumento da segurança como tendência futura em todos os espaços considerados pela grande maioria dos elementos da CE, o que, como acima se referiu, constitui um resultado bastante atípico comparativamente com outros estudos (M.L. Lima, 2005; A. Delicado et al., 2007). Outra possível explicação diametralmente oposta à tendência de negação do risco por parte das populaçóes encontrar-se-ia numa adoção mais ou menos generalizada da reação adaptativa do optimismo persistente anunciada por A. Giddens (1992), em que os indivíduos acreditam e confiam no advento de novas soluçôes científicas, sociais e tecnológicas para os principais problemas no futuro. 


\section{Perceçáo do risco por tipologia de espaço}

Há riscos cuja carga simbólica, mais do que a probabilidade efetiva da sua concretizaçáo ou os seus potenciais efeitos, os torna especialmente temidos; outros riscos merecem especial atenção dos media; outros suscitam relevância especial para certas populaçôes. Estando a perceção dos riscos também associada às suas características, natureza e aos contextos temporal e espacial, procurou-se compreender como sáo percecionados os diferentes riscos pelos elementos da CE. Assim, foi questionado o grau de preocupação suscitado por um conjunto de potenciais riscos relativamente aos espaços de casa, à escola e ao bairro dos Olivais, medindo-se essa preocupação numa escala ordinal de 5 níveis (1 - não me preocupa nada a 5 - preocupa-me muito). De uma maneira geral, os inquiridos manifestaram em todos eles graus de preocupaçáo médio a relativamente elevado, com níveis quase sempre superiores a 3.

No que diz respeito aos riscos que suscitaram mais preocupação em casa e na escola, destacam-se os perigos de sismo e de incêndio (com valores médios de 3,73 e 3,62, respetivamente), o que constitui uma perceção desejável da perigosidade real, tendo em conta que são precisamente as duas situaçôes previstas como de maior perigosidade nos planos de prevenção e emergência dos estabelecimentos escolares. Contudo, estes resultados são surpreendentes, nomeadamente no que diz respeito à elevada preocupaçáo manifestada em relação aos sismos; noutros estudos similares, é frequentemente constatada uma menor preocupação com os perigos provocados por fenómenos naturais considerados pouco prováveis, como é o caso dos sismos (A. Delicado et al., 2007). É ainda de assinalar o elevado grau de preocupaçáo manifestado na escola para o risco de contágio de doenças graves (valor médio de 3,5), relacionando-se um problema de saúde pública com um espaço de utilização coletiva.

Uma outra interpretaçâo plausível seria considerar que uma parte destes resultados constituía uma consequência das iniciativas de sensibilização já concretizadas junto da CE da ESEQ. Uma outra provável explicação poderá relacionar-se com as notícias amplamente difundidas pelos media sobre os sis- 
mos ocorridos na Nova Zelândia e no Japão durante a realização do inquérito. Ambas as hipóteses carecem de confirmação.

Os resultados do inquérito revelaram que há uma tendência para que os riscos mencionados como mais preocupantes serem os que mais escapam ao controlo dos indivíduos (que têm reduzidas possibilidades de agirem para os evitarem), aumentando assim a sua sensação de impotência e de vulnerabilidade, como é o caso dos sismos, doenças contagiosas e da guerra/terrorismo/atentados (A. Delicado et al., 2007). Pelo contrário, perigos que são percecionados como mais distantes ou improváveis, ou que consideram poder ser mais facilmente controláveis, tendem a ser desvalorizados. É o caso dos tsunamis e das cheias/ inundação, em parte devido também ao facto de a escola se situar num local elevado, o que certamente influenciará a perceção relativamente a estes riscos.

Procurou-se ainda averiguar a existência de eventuais diferenças significativas no grau de preocupaçáo manifestada pelos elementos da CE aos riscos de sismo e incêndio no espaço da escola. Pela análise da fig. 5, conclui-se que os alunos e os professores manifestaram menores valores médios de preocupação ao risco de incêndio e de sismo, enquanto os assistentes operacionais e técnicos tenderam a apresentar valores médios superiores para ambos (excetuando o caso dos sismos por parte dos professores que foi ligeiramente mais alto que o verificado para os assistentes operacionais).

Apesar dos dados obtidos apenas compararem o grau de preocupação entre os riscos de sismo e incêndio, poder-se-á concluir da não existência de uma relação entre o nível de qualificação académica e a perceção de riscos. A literatura neste domínio tem mostrado uma maior sensibilização ao risco por parte dos grupos socialmente menos favorecidos, isto é, nos menos escolarizados e nos que têm menores rendimentos (M.L. Lima, 2005; M. Queirós, 2009). Apesar das diferenças não serem muito significativas, os alunos constituem a categoria da CE com menores graus de preocupação com o risco de sismo e os professores com o risco de incêndio, o que constitui provável indício da necessidade de uma maior sensibilização a estas duas categorias de elementos da CE.

A fig. 6 traduz a informaçáo resultante da questáo onde se pedia à população inquirida que assinalasse a maior possibilidade de ocorrência na escola 


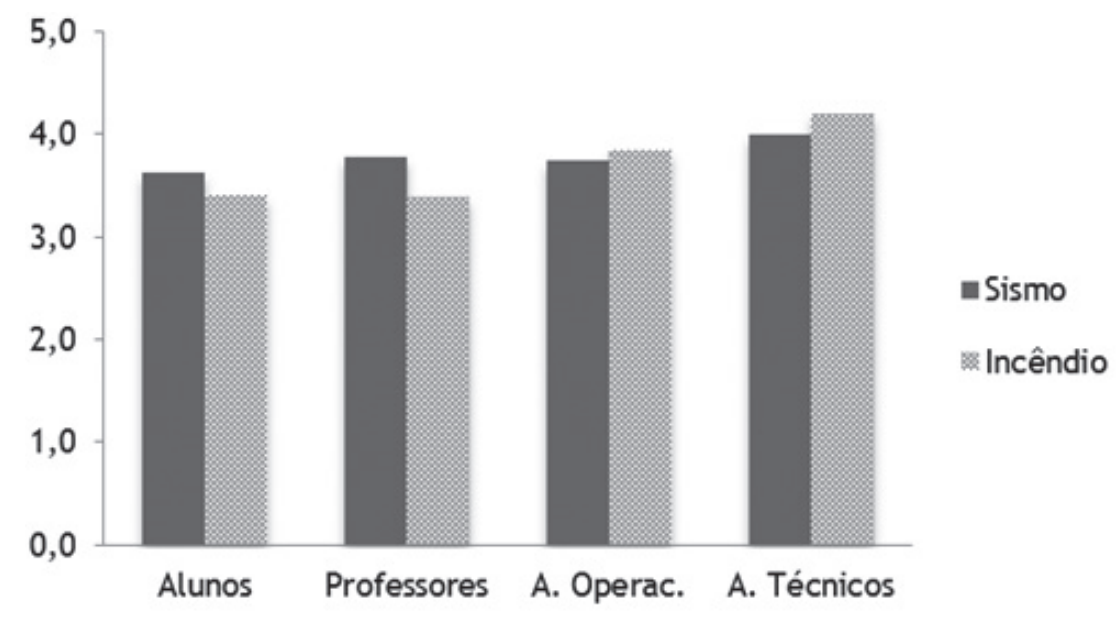

1-Não me preocupa nada 5-Preocupa-me muito

Fig. 5 - Grau de preocupaçáo aos riscos de sismo e incêndio na escola (Fonte: A. Machado, 2012).

Fig. 5 - Degree of concern to the risks of earthquake and fire at school (Source: A. Machado, 2012).

de cada um dos riscos dentro de um horizonte temporal $(1,10,50$, mais de 50 anos e nunca).

Apesar de uma significativa parte dos inquiridos ter manifestado dificuldade em responder a esta questão, o que poderá indiciar uma certa dificuldade na perceção da ocorrência provável dos riscos a que se pode estar exposto, constatase uma nítida predominância das respostas em relaçáo à maior possibilidade de ocorrência (1 ano), dos riscos de tabaco/droga/toxicodependência, insegurança (assalto/roubo) e contágio de doenças graves, todas com percentagens superiores a $50 \%$. Num cenário com uma possibilidade a 10 anos, foram assinalados como mais prováveis os riscos de incêndio, tempestade/ciclone, cheia/inundação e sismo com respostas superiores a $30 \%$. Com uma possibilidade de ocorrência a 50 anos, foi referido com $26 \%$ de respostas, o risco de guerra/terrorismo/ atentado, sendo considerada nula a probabilidade do risco de tsunami com $29 \%$ das respostas. 


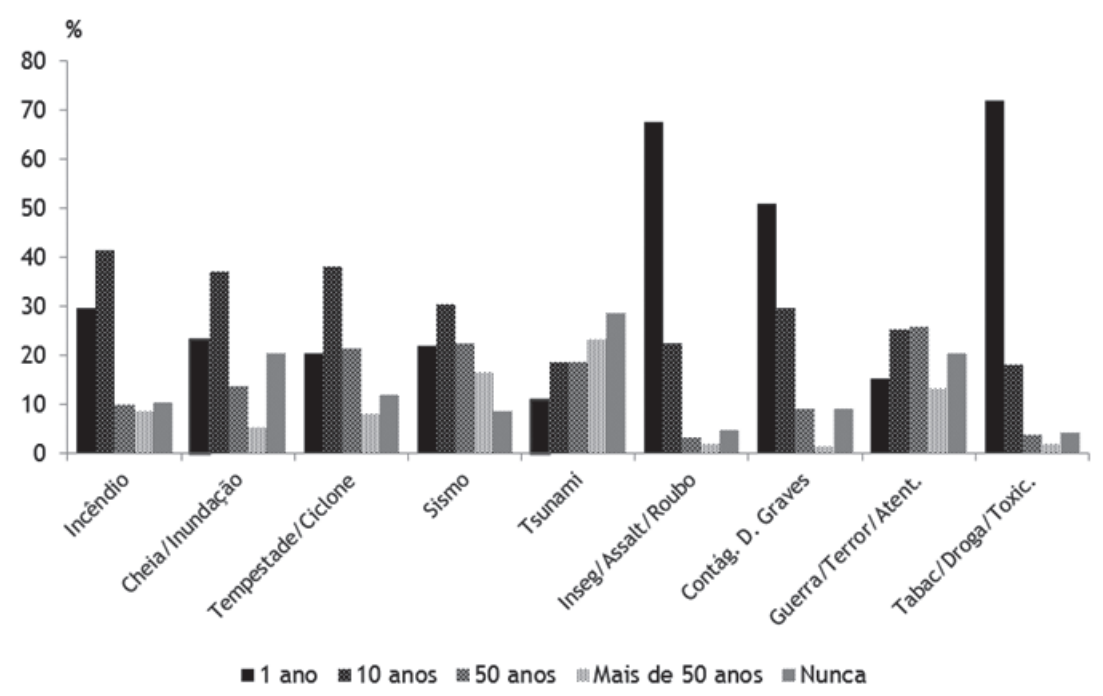

Fig. 6 - Possibilidade de ocorrência dos riscos na escola (Fonte: A. Machado, 2012).

Fig. 6 - Possibility of occurrence of the risks at school (Source: A. Machado, 2012).

Relativamente às dificuldades manifestadas na realização de estimativas subjetivas da frequência e probabilidade da ocorrência dos riscos, existe investigação que demonstra que as pessoas colocadas perante a necessidade de fazerem julgamentos complexos ou tomar decisôes com muitas variáveis usam estratégias de simplificação. Estas heurísticas são facilitadoras da decisão, mas conduzem simultaneamente a erros sistemáticos e previsíveis. Segundo F. Bernardo (1997), uma das estratégias mentais frequentemente utilizadas em situaçóes nas quais é necessário avaliar a possibilidade de ocorrência de um acontecimento, é a heurística de disponibilidade de um acontecimento ou ocorrência. Neste caso, verifica-se frequentemente que o sujeito é influenciado pela facilidade com que o acontecimento ou ocorrência é recordada, considerando o fenómeno mais recente como mais frequente e provável.

A heurística da disponibilidade tem também consequências na comunicação dos riscos, uma vez que a mera divulgaçáo de um perigo leva a um aumento da preocupação. Deste modo, as notícias na comunicação social acerca de uma determinada fonte de risco, ao tornarem mais disponíveis exemplos específicos, tendem 
a produzir uma inflaçáo do risco percebido (M.L. Lima, 2005), facto considerado pertinente na definição de um plano de comunicação eficaz do risco. Esta heurística da disponibilidade poderá explicar, em parte, o relativamente elevado grau de preocupação manifestado em relação ao risco sísmico, devido aos já mencionados eventos/catástrofes naturais ocorridos na Nova Zelândia e no Japão durante a realização do presente inquérito, e que foram amplamente noticiados pelos media.

\section{A confiança nas fontes de informação sobre os riscos}

As perceçôes e os comportamentos do público perante o risco são fortemente influenciados pela sua apreciaçáo da forma como o risco é avaliado e gerido

pelas entidades competentes. É frequente a discordância nos discursos sobre o risco (existência ou não existência, dramatização ou minimização) por parte dos diferentes atores (Estado, técnicos, associações ambientalistas e de consumidores, jornalistas, profissionais de saúde, etc.). De acordo com A. Tavares et al., (2011), as questóes da confiança e da credibilidade adquirem uma importância central para a relativização do risco e para a cultura de segurança e a resiliência das comunidades (tópico 6 da Tabela I).

A credibilidade das instituiçôes e a confiança nelas depositadas variam, desde logo, consoante a natureza da própria instituição (governo, indústria, grupos ambientalistas/de consumidores), sendo igualmente condicionadas por factores como a capacidade técnica (no que respeita aos técnicos), a abertura e a honestidade (relativamente às autoridades públicas) e a preocupação e cuidados demonstrados (no que respeita às empresas) (A. Delicado et al., 2007). Se a populaçáo tiver vivido, por exemplo, uma situaçáo anterior de ocultaçáa ou minimização da informação sobre o risco por parte destas entidades, tenderá a depositar nelas menor confiança.

Considerando estas questôes, pretendeu-se avaliar a confiança demonstrada pelos elementos da CE nos diferentes agentes/instituiçóes, fonte de informação do risco à população (fig. 7). Assim, o questionário solicitou aos inquiridos que avaliassem o seu grau de confiança na informação/aconselhamento que os 
diversos agentes fornecem sobre a segurança, prevenção e mitigaçáo dos riscos à populaçáo, numa escala de 1 a 5 ( 1 - nenhuma confiança, 5 - confiança total).

A análise dos resultados permite concluir que são os agentes de proteção civil (bombeiros e polícia) e os profissionais de saúde que granjearam a maior confiança dos elementos da comunidade (com um valor médio de 3,7). Esta confiança parece demonstrar o reconhecimento do papel fundamental na atuaçáo, aconselhamento e difusão de mensagens de prevenção de riscos, assim como da credibilidade, segurança e valorizaçáo positiva da sua atuaçáo em situaçôes de emergência.

O discurso científico e dos técnicos também parece estimular sentimentos de empatia e de confiança entre a população inquirida (valor médio de 3,62). De acordo com M. Queirós (2009), estes resultados estáo em desacordo com os estudos internacionais, onde se tem demonstrado que as sociedades pós-industriais tendem a ter uma relação ambígua em relação à ciência; a amplificação dos perigos associados ao desenvolvimento científico e tecnológico pelos media, justifica uma atitude mais crítica por parte das populaçóes.

No entanto, em Portugal, regista-se uma confiança considerável na ciência para resolver os assuntos mais problemáticos (M. Queirós, 2009), facto que os dados do inquérito parecem confirmar e que podem em parte ser explicados pelas baixas taxas de escolaridade, qualificação e esclarecimento da população em geral, favorecendo a opiniáo acerca das capacidades dos mais qualificados. A. Giddens (1992) considerava que a grande maioria das pessoas não perde muito tempo, pelo menos conscientemente, a preocupar-se com os perigos que não controlam. A necessidade de lidar com as questôes práticas da vida quotidiana é, sem dúvida, uma razão para isso. O sentimento de que, apesar de tudo, as ameaças haverão de ser solucionadas por alguém supostamente mais próximo e habilitado e poderoso do que nós, acalma a ansiedade mas também produz indiferença.

A instituição escola/professores e as associaçóes ambientalistas e/ou de consumidores suscitaram também níveis elevados de confiança na informação e aconselhamento dos riscos (valor médio 3,5), o que constitui um valioso capital de confiança social que deve ser devidamente considerado e aproveita- 


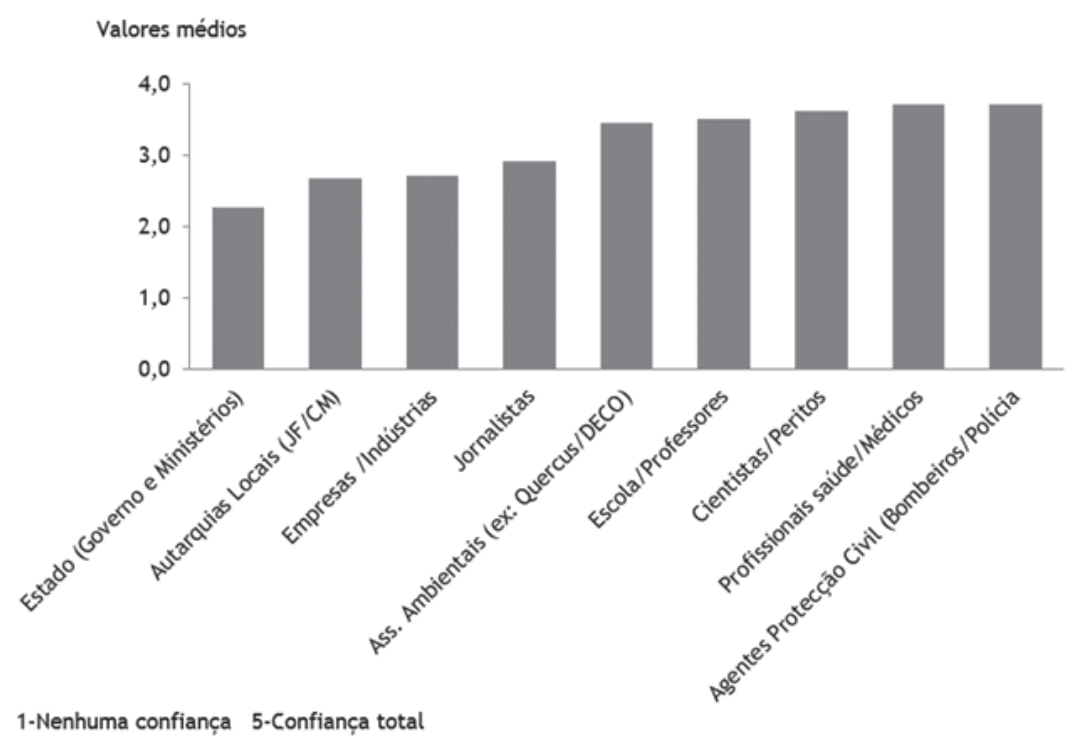

Fig. 7 - Confiança atribuída à informação transmitida pelos agentes/instituições (Fonte: A. Machado, 2012).

Fig. 7 - Trust attributed to information provided by agents / institutions (Source: A. Machado, 2012).

do, nomeadamente pelos órgãos de administração escolar, na implementação de medidas de sensibilização e mobilização da comunidade para as questōes relacionadas com os riscos em espaço escolar.

Os dados apurados permitem também registar que este processo pode ser significativamente facilitado apelando-se à colaboração dos agentes de proteção civil, tendo em conta a confiança demonstrada pelos inquiridos. Por outro lado, a escola não deverá hesitar em solicitar apoio e orientação técnica aos agentes locais e municipais de proteção civil, pois o estabelecimento de contatos regulares facilita o conhecimento mútuo, os recursos disponíveis e ainda a coordenação e a assistência prestada durante as emergências (A. Machado, 2012).

As empresas, as autarquias locais e a administração central constituem as entidades em que foi depositada menor confiança. Estes dados convergem, em larga medida, com os estudos anteriores (A. Delicado et al., 2007, A. Tavares et al., 2011). Este sentimento de desconfiança da opiniâo pública em relaçấo às 
instituições governamentais deve-se em grande parte a um discurso político que recorre frequentemente a estratégias de ocultação, distorção e negação dos factos, elevação dos níveis de permissividade e ênfase nos erros humanos e não nos erros de sistema (U. Beck, 2006; A. Delicado et al., 2007). Além do mais, a falta de transparência e de comunicação, a inexistência de uma prática de prestação de contas e a atribuição de responsabilidades das instituições quase sempre inconsequentes, contribuem também para os baixos níveis de confiança gerados na opinião pública acerca dos poderes públicos nos assuntos dos riscos. A falta de confiança que as pessoas manifestam no governo (valor médio 2,26), ligeiramente inferior ao das autarquias, que apresentam um grau de confiança de 2,68, é uma expressão de mal estar generalizado que as populaçôes sentem atualmente em relação às instituições políticas e que não é exclusivo de Portugal, como aliás sucessivas sondagens e estudos de opinião têm dado conta (M. Queirós, 2000; 2009).

\section{A participação e o grau de envolvimento da Comunidade Escolar}

Nesta secção do questionário, pretendeu-se averiguar qual o grau de envolvimento e participação da CE em relação aos riscos. Num país onde a sociedade civil é tradicionalmente pouco ativa, procurou-se avaliar o empenho e participação dos elementos da CE, relativamente à forma como procuram informar-se (ou não) sobre os riscos. Existem estudos que relatam fortes correspondências entre a procura de informação junto de diversas fontes de informação como instituiçôes governamentais e organizaçóes não governamentais (ONG) e a adopção de medidas preventivas (K. Ronan et al., 2005). Assim, conclui-se que a procura ativa de informação sobre riscos junto de várias fontes é um comportamento preditivo de tomada efetiva de medidas de prevenção.

Observa-se na fig. 8 que a maior parte dos inquiridos assinalaram os media tradicionais como principal fonte de informação (79\%), de onde se destaca a televisão, o que revela uma atitude passiva, de receção, e não ativa, de procura deliberada de informação; a internet surge em segundo lugar como fonte proativa de informação. Já o contacto com entidades responsáveis é quase residual: os bom- 
beiros e a polícia (6\%), associaçôes ambientalistas e de consumidores e médico de família ( $2 \%$ cada). A igualmente baixa percentagem de respostas relativas à procura de informaçáa junto da escola/professores (2\%), constitui um dado igualmente preocupante. Contudo, o conhecimento destes modelos de perceção revela um desafio para que a escola equacione e implemente novas formas de sensibilização por forma a incrementar os níveis de interesse, confiança e participação dos elementos da comunidade na instituição educativa; a complementaridade com a internet junto das camadas mais jovens da CE parece ser relevante.

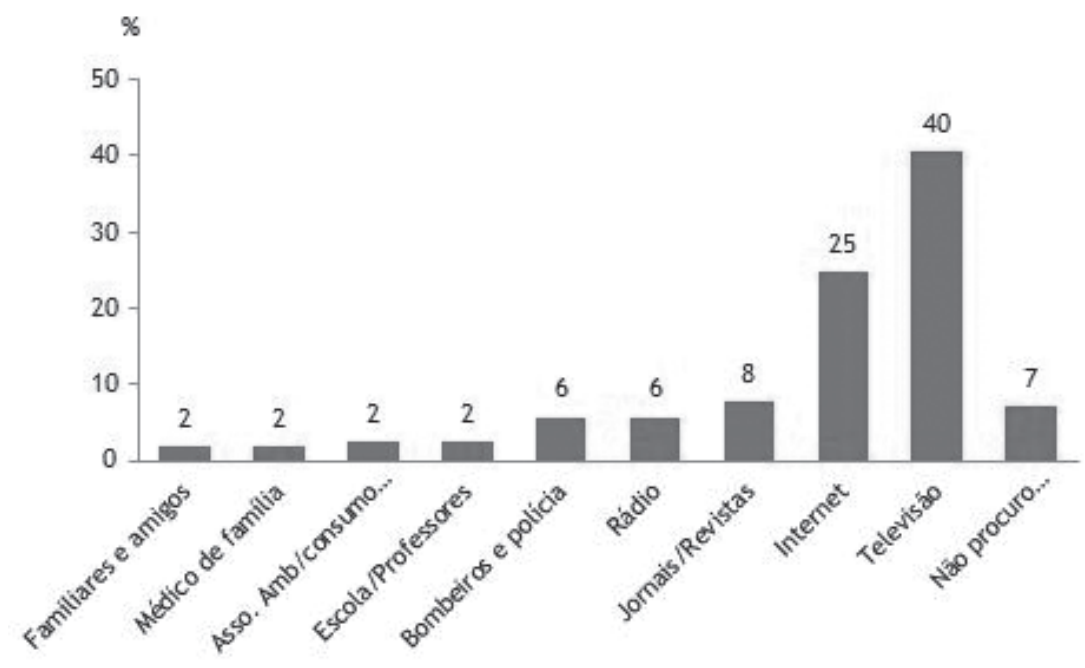

Fig. 8 - Principal fonte de informação sobre riscos (Fonte: A. Machado, 2012). Fig. 8 - Main sources of information on risks (Source: A. Machado, 2012).

\section{A prevenção, o conhecimento e a experiência dos riscos}

Este último conjunto de questóes pretendeu avaliar que medidas de prevenção são tomadas pelos inquiridos, que conhecimentos possuem face às emergências e qual a sua experiência pessoal com situaçôes reais de sismo e de incêndio.

Para se avaliar que medidas de prevenção e mitigação de riscos são empreendidas pelos indivíduos ou pela sua família, foi solicitado que assinalassem, 
a partir de uma lista composta por sete itens, aquela(s) que considerassem corresponder ao seu caso (fig.9). O apuramento percentual dessas escolhas revela que dos sete itens, cinco registaram percentagens de resposta superiores a $40 \%$, destacando-se o corte de água e gás aquando da ausência de casa durante vários dias. Estes resultados constituem um indício relativamente satisfatório da conduta dos elementos inquiridos relativamente à prevenção dos riscos.

Já o mesmo não se pode afirmar em relação à existência de um extintor em casa: apenas um quarto dos indivíduos assinalaram a posse deste meio de $1^{\circ}$ socorro. Este dado está em desacordo com aquilo que foi apurado anteriormente (onde o risco de incêndio em casa surge logo com o segundo maior grau de preocupaçáo). Esta aparente contradiçáo pode ser em parte explicada pela heurística do otimismo comparativo ou otimismo irrealista e que explica porque é que apesar de os indivíduos reconhecerem a existência de um risco, desenvolvem frequentemente a presunçáo de que não lhe são vulneráveis. Verifica-se uma tendência a subavaliar os riscos que corremos e que pensamos controlar, sendo mais fácil reconhecer os perigos a que os outros estấo sujeitos (M. L. Lima, 2005). Finalmente, o plano de emergência familiar foi mencionado apenas por $13 \%$ dos inquiridos, o que era expetável, tendo em conta a menor facilidade de implementação face à sua menor divulgação, necessidade de sensibilização, organização e mobilização de todos os elementos da família.

As questóes que avaliam o conhecimento dos indivíduos relativos aos comportamentos adequados a tomar em caso de emergência, em geral, e ao plano de emergência da escola, em particular, revelaram, no primeiro caso, valores relativamente elevados de respostas a todos os itens considerados, variando entre os $41 \%$ para a saída adequada da escola em caso de sismo e os $62 \%$ na procura de locais seguros ao sismo em casa. Constata-se uma maior dificuldade nas respostas relativas ao espaço escolar e à rua do que em relação às atitudes corretas a tomar em casa, o que já era esperado, confirmando a necessidade de prosseguir com a sensibilização sobre as medidas de autoproteção, especialmente em caso de sismo, e a realização de exercícios anuais de evacuação das instalações escolares.

Foi demonstrado que os programas de sensibilização para prevençấo das emergências conhecem maior eficácia quando se sugerem açôes concretas do 


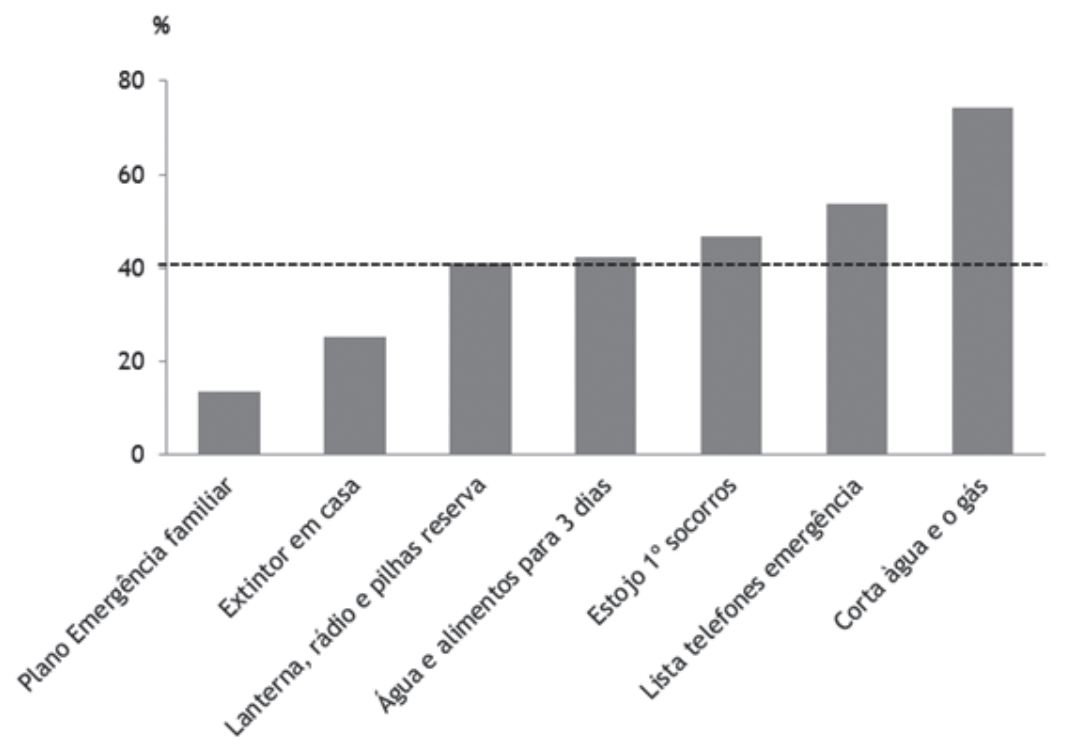

Fig. 9 - Medidas de prevenção empreendidas pelo próprio e/ou pela família.

(Fonte: A. Machado, 2012).

Fig. 9 - prevention measures undertaken by itself and/or family.

(Source: A. Machado, 2012).

que é correto realizar, comparativamente quando se mostram apenas imagens dos danos provocados. Os indivíduos que assistem a imagens de destruição são capazes de se lembrar mais facilmente delas após seis meses, mas em termos de motivação para a ação, os efeitos demonstraram ser negligenciáveis. Pelo contrário, as pessoas que frequentaram campanhas onde foram indicadas medidas concretas e comportamentos adequados a tomar revelaram um significativo efeito nos esforços de prevenção. $\mathrm{O}$ mesmo foi verificado relativamente à prática e cumprimento de um plano de emergência, onde se voltou a verificar que a demonstração do que se deve fazer é preferível a visionar imagens de destruição provocadas pelos desastres (K. Ronan et al., 2005).

A fig. 10 traduz um relativamente elevado conhecimento de alguns aspetos relacionados com o plano de emergência da escola por se registarem valores superiores a $50 \%$ em praticamente todos os itens, demonstrando o efeito positivo das ações de sensibilização já realizadas no que diz respeito ao conhecimento 
e participação nos exercícios de evacuação, considerados imprescindíveis para uma preparação adequada da CE às situaçóes de emergência.

A última informação recolhida pretendia avaliar a experiência pessoal dos inquiridos com situaçóes de incêndio e sismo, precisamente os riscos que são considerados no plano de segurança da escola. Foram constatados valores relativamente baixos, dado constituírem riscos de baixa frequência. Os alunos destacam a experiência direta com situaçóes de incêndio (12\%), enquanto $9 \%$ dos professores registam um contacto com pelo menos uma situação de sismo. Os assistentes operacionais e técnicos registaram valores substancialmente mais reduzidos ou mesmo nulos. Esta informação é considerada relevante tendo em conta a importância da memória na perceção dos perigos. Um acidente memorável faz com que um risco seja mais facilmente lembrado, podendo, por isso, suscitar um sentimento de maior ameaça (A. Machado, 2012; M. Queirós e A. Santos, 2013; A. Santos e M. Queirós, 2015).

As experiências pessoais com o risco são um elemento importante na explicação da perceção, na medida em que se tende a atribuir a eles maior importância, mesmo quando comparados com outros estatisticamente mais relevantes. Como já anteriormente mencionado, este processo mental é designado por heurística da disponibilidade de um acontecimento ou ocorrência (F. Bernardo, 1997),

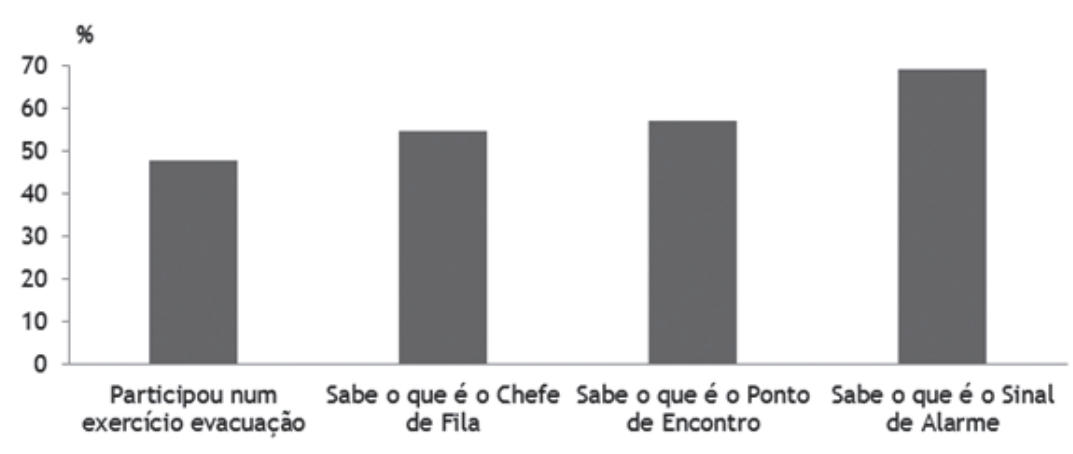

Fig. 10 - Participação e conhecimento do Plano de Emergência da escola.

(Fonte: A. Machado, 2012).

Fig. 10 - Participation and knowledge of the School Emergency Plan.

(Source: A. Machado, 2012). 
que explica o facto de os indivíduos tenderem a valorizar a ocorrência de acontecimentos que conhecem e de subestimarem a frequência de outros de que não se lembram de exemplos concretos (M.L. Lima, 2005). Compreendese assim a forma como as pessoas são influenciadas pela facilidade com que um acontecimento ou ocorrência é recordada, considerando o fenómeno mais recente como mais provável e frequente.

\section{Síntese: a prevenção dos riscos na comunidade escolar}

Considerando a diversidade valorativa registada pela CE na participação das atividades promotoras da segurança no espaço escolar, o questionário aplicado na ESEQ objetivou o estudo da perceção e o grau de interiorização da noção de risco na CE (A. Machado, 2012). Procurou ainda avaliar até que ponto a ideia de risco está incorporada na CE e como varia essa perceção consoante as suas características sociodemográficas, as categorias de risco e nos espaços considerados relevantes do quotidiano dessa comunidade. Por outro lado, pretendeu conhecer a confiança depositada na informação transmitida pelos media e pelos diferentes agentes e instituiçóes com responsabilidades nesta matéria, a sua participaçáo, conhecimento e experiência pessoal com situaçôes de emergência, de modo a formular estratégias de comunicação adequadas e eficazes na prevenção e mitigação de riscos. Demonstrou também que na formação das perceçóes e dos comportamentos face aos riscos, intervêm ainda um conjunto de fatores, mais ou menos subjetivos que vão desde a familiaridade com a fonte e os efeitos do perigo, a capacidade de controlo do grau de risco, o potencial catastrófico de que o perigo se reveste e a confiança depositada quer nas fontes de informação disponíveis, quer nas entidades com responsabilidades na gestão do risco (A. Machado, 2012).

Apesar do relativamente elevado grau de preocupação suscitado pela maior parte dos riscos considerados no inquérito, foi detetada uma passividade generalizada em face deles. Os inquiridos procuram (ou melhor, recebem) informação sobre estas matérias através dos media, sobretudo da televisão. De acordo com 
os dados apurados, é clara a fraca confiança nas instituiçóes públicas e nas empresas/indústrias e, paradoxalmente, nos jornalistas. A relação com os media é, simultaneamente, de dependência e desconfiança: os indivíduos precisam deles para acederem à informação, mas exprimem reservas quanto à exatidão da informação por eles transmitida.

A noção de impotência associada aos riscos agudos e potencialmente catastróficos opóe-se ao falso sentimento de controlo de acontecimentos focalizados no quotidiano (elevados sentimentos de segurança no dia a dia). Significa isto que se regista uma sensibilidade da CE para as catástrofes incontroláveis, com amplos efeitos danosos e de consequências trágicas (sismos, incêndios), ao mesmo tempo que tende a desvalorizar e a sentir um otimismo irrealista sobre os riscos difusos e controláveis (tabaco/droga/toxicodependência).

A confiança e credibilidade demonstrada nas forças de proteção civil, nos cientistas e nos movimentos ambientalistas/consumidores, por oposição às empresas e às instituiçóes do Estado, confirmam o que foi também constatado noutros estudos, tanto nacionais como internacionais. A instituiçáo escola/professores suscitou também níveis elevados de confiança na informação e aconselhamento dos riscos, o que constitui um valioso capital de confiança social que deve ser devidamente considerado e aproveitado, nomeadamente pela Direção, na implementação de estratégias de comunicação que estimulem atitudes de maior prevenção e preparação ao risco e de medidas de sensibilização e mobilização da comunidade para as questôes relacionadas com a segurança e a resiliência aos riscos a que está exposta no espaço escolar. Estas açóes de sensibilização devem ter uma frequência regular e, no sentido de potenciar a sua eficácia, devem suscitar níveis de preocupação moderados, fornecer informação e instruçôes sobre os diferentes danos provocados por um perigo e sobre aqueles que poderão ser objeto de prevenção e mitigação, de forma específica, concreta e credível e consistente com outras fontes de informação. Este processo de sensibilização pode ser significativamente facilitado apelando-se à colaboração dos agentes de proteção civil, cientistas, e associaçôes ambientalistas/ consumidores, tendo em conta a elevada confiança demonstrada pelos inquiridos. Por outro lado, a escola não deverá hesitar em solicitar apoio e orientação técnica aos agentes locais e municipais de proteção civil, pois o estabelecimento de con- 
tatos regulares facilita o conhecimento mútuo, os recursos disponíveis e ainda a coordenação e a assistência prestada durante as emergências. Estas intervenções contribuem para uma melhor preparação e recuperação da CE às emergências, já que a podem ajudar a perceber o que a espera numa situaçáo de desastre, que equipamentos de $1^{\circ}$ socorro devem instalar e usar, e que exercícios e treinos devem realizar nas suas instalações.

Finalmente, cada exercício de evacuação e/ou simulação realizado, deve ser objeto de uma avaliaçáo, identificando-se os comportamentos mais adequados mas também aqueles que não corresponderam às expetativas e que devem ser objeto de análise de forma a serem identificadas as causas que estiveram na origem do mau desempenho. Este aspeto reveste-se de grande importância, pois o incremento de resiliência da CE aos riscos prende-se diretamente com as aprendizagens adquiridas com as experiências anteriores (que apoiam a construção da designada “memória muscular" - M. Queirós e A. Santos, 2013), por forma a alcançar no futuro uma maior funcionalidade, autonomia e capacidade em lidar e recuperar de situaçóes adversas e de stress, como é o caso das relacionadas com a absorção de desastres, e a gestão da emergência.

Por tudo o que foi exposto, seria importante que outras CE realizassem estudos similares, dinamizadores de uma nova consciência do risco e da validade da prevenção, mitigação e resiliência aos desastres nas escolas portuguesas; estas CE poderiam organizar-se em rede e, pela partilha de experiências e competências, constituir em situaçóes de emergência "polos de resiliência" no território, contribuindo para uma efetiva redução das vulnerabilidades das populaçóes e para uma gestão mais eficaz das catástrofes (A. Machado, 2012).

No espaço urbano, onde a mobilidade é grande e o conhecimento das características do território menor, as informaçóes sobre os riscos e os comportamentos e atitudes ajustados aos perigos existe predominantemente ao nível institucional e, como tal, a escola deve ocupar uma posição estratégica na promoção social da cultura de prevenção e de segurança, indispensável na construção de comunidades resilientes. 


\section{Referências bibliográficas}

Abreu, Diogo (2006) Análise de Dados II, Estudos para o planeamento regional e urbano ${ }^{\circ} 69$, Centro de Estudos Geográficos, Universidade de Lisboa.

Beck, Ulrich (2006). La Sociedad del Riesgo. Barcelona, Paidós.

Bernardo, Fátima (1997) Perceçâo pública de riscos e planos de intervenção. Centro Nacional de Informação Geográfica, Lisboa.

Cutter, Susan, Barnes, Lindsey, Berry, Melissa, Burton, Christopher, Evans, Elijah, Tate, Eric e Webb Jennifer (2008). Community and regional resilience: perspectives from hazards, disasters, and emergency management. Research Report. Community and Regional Resilience Institute (CARRI) and Science Advisor Savannah River Nacional Laboratory, Oak Ridge. http://www.resilientus.org/publications/reports.html (Acedido em 11 de Janeiro de 2011)

Delicado, Ana e Gonçalves, Maria E. (2007). Os portugueses e os novos riscos: resultado de um inquérito. Análise Social, XLII (184), 687-718.

Douglas, Mary (1992). Risk and Blame: Essays in Cultural Theory. Routledge, USA.

Figueiredo, Elisabete, Valente, Sandra, Coelho, Celeste e Pinheiro, Luísa (2004). Conviver com o risco - $A$ importância da incorporação da percepção social nos mecanismos de gestão de cheia no concelho de Águeda. Centro de Estudos Sociais. Universidade de Coimbra. http://www.ces.uc.pt/lab2004/pdfs/ElisabeteFigueiredo_Valente_coelho_LuisaPinheiro.pdf

Frias, Graça (2004). A construção social do sentimento de insegurança em Portugal na actualidade. Centro de Estudos Sociais. Universidade de Coimbra. http://www.ces.uc.pt/lab2004/pdfs/ gracafrias.pdf

Giddens, Anthony (1992). As Consequências da Modernidade. Celta, Oeiras

Inácio, Maria (2010). A Promoção de uma cultura de segurança nos alunos do ensino básico: um estudo de caso nos segundo e terceiro ciclos (Dissertação de Mestrado interdisciplinar em Dinâmicas sociais, Riscos Naturais e Tecnológicos). Faculdade de Economia da Universidade de Coimbra, 97p. Disponível em: http://hdl.handle.net/10316/14327

Holling, Crawford (1973). Resilience and stability of ecological systems. Annual Review of Ecology and Systematics, 4: 1-23.

ISDR (2005). World Conference on Disaster Reduction. Proceedings of the Conference. Building the Resilience of Nations and Communities to Disasters. ONU. Disponível em: http://www.unisdr. org/wcdr/thematic-sessions/WCDR-proceedings-of-the-Conference.pdf

Kano, Megumi e Bourque, Linda (2007). Experiences with and preparedness for emergencies and disastres among public schools in California. NASSP Bulletin. Sage, 91:201-218.

Lima, Maria (1995). Viver com o risco: abordagens da Psicologia social ambiental. Inforgeo, 9/10: 39-54.

Lima, Maria (2004). Percepção de riscos ambientais: realismo ou ilusão? Ambiente e Desenvolvimento, 157-192.

Lima, Maria (2005). Percepção de Riscos Ambientais. In Soczka L. (ed) Contextos Humanos e Psicologia Ambiental. Fundação Calouste Gulbenkian, Lisboa: 203-245.

Machado, André (2012). Percepção do risco e implementação de uma cultura de segurança: construindo comunidades educativas resilientes. Dissertação de Mestrado em População, Sociedade e Território. IGOT, Universidade de Lisboa, 114p. Disponível em: http://repositorio.ul.pt/handle/10451/9352. 
Quaresma, Ivânia (2008). Inventariação e Análise de Eventos Hidro-geomorfológicos com Carácter Danoso em Portugal Continental. Mestrado em Geografia Física. IGOT, Universidade de Lisboa. Disponível em: http://repositorio.ul.pt/handle/10451/427.

Queirós, Margarida, Vaz, Teresa e Palma, Pedro (2006). Uma Reflexão a Propósito do Risco. Centro de Estudos Geográficos, Lisboa. Disponível em: http://www.ceg.ul.pt/ERSTA/..\%5CDescarga \%5CERSTA\%5CMQ_TV_PP.pdf.

Queirós, Margarida (2000). Uma reflexão sobre as perspectivas metodológicas na análise do risco ambiental. Colóquio Geografia dos Riscos, Planigeo, Lisboa, FLUL.

Queirós, Margarida e Henriques, Eduardo (2009). (In)Segurança numa regiáo de elevada susceptibilidade: implicaçôes para a gestão do risco, Ed. Salamandra, Lisboa: 181-200.

Queirós, Margarida e Santos, Ângela, (2013). Segurança contra incêndios em edifícios públicos universitários: uma reflexão a partir de um exercício-piloto de evacuaçẫo na Universidade de Lisboa. Livro de Homenagem ao Prof. Fernando Rebelo, Universidade de Coimbra, Cap.3:543553. Disponível em: https://sites.google.com/a/campus.ul.pt/tsurima/publications/b-chapter-of-books

Ronan, Kevin e Johnston, David (2005). Promoting Community Resilience in Disasters. The role for schools, youth and families. New York, Springer.

Santos, Angela e Queirós, Margarida (2015). Public buildings safety: Addressing a pilot evacuation exercise. Nowakowski et al. (Eds.), Safety and Reliability: Methodology and Applications, Taylor \& Francis Group, London, pp. 2009-2015. ISBN 978-1-138-02681-0.

Santos, Fernando, Partidário, Maria (2011) SPARK: Strategic Planning Approac for Resilience Keeping. European Planning Studies, 19. Disponível em: http://www.tandfonline.com/doi/ abs/10.1080/09654313.2011.533515

Slovic, Paul (2000). The Perception of Risk. Earthscan, London.

Tavares, Alexandre, Mendes, José e Basto, Eduardo (2011). Perceção dos riscos naturais e tecnológicos, confiança institucional e preparação para situaçōes de emergência: $O$ caso de Portugal continental. Revista Crítica de Ciências Sociais (Online) 93. Disponível em: http://rccs.revues.org/1380.

Zêzere, José, Ramos, Ana e Morgado, Paulo (2007b). Perigos Naturais em Portugal e Ordenamento do Território. E depois do PNPOT? Geographilia - o sentir e os sentidos da Geografia. CEG: 529-542.

Zêzere, José, Ramos, Ana e Morgado, Paulo (2006). Perigos Naturais e Tecnológicos no território de Portugal Continental. Centro de Estudos Geográficos. Disponível em: http://www.apgeo. pt/files/docs/CD_X_Coloquio_Iberico_Geografia/pdfs/091.pdf

Zêzere, José, Ramos, Catarina, Reis, Eusébio, Garcia, Ricardo e Oliveira, Sérgio (2007a). Perigos Naturais, Tecnológicos e Ambientais na Regiāo do Oeste e Vale do Tejo. Inforgeo, 22/23: 37-49. 